\title{
Inhibition of pulmonary nuclear factor kappa-B decreases the severity of acute Escherichia coli pneumonia but worsens prolonged pneumonia
}

\author{
James Devaney ${ }^{1,2}$, Gerard F Curley ${ }^{1,3}$, Mairead Hayes ${ }^{2}$, Claire Masterson², Bilal Ansari², Timothy O'Brien',
} Daniel O'Toole ${ }^{1,2}$ and John G Laffey ${ }^{1,3^{*}}$

\begin{abstract}
Introduction: Nuclear factor (NF)- $\kappa$ B is central to the pathogenesis of inflammation in acute lung injury, but also to inflammation resolution and repair. We wished to determine whether overexpression of the NF- $\kappa \mathrm{B}$ inhibitor $\mid \kappa \mathrm{B} \alpha$ could modulate the severity of acute and prolonged pneumonia-induced lung injury in a series of prospective randomized animal studies.

Methods: Adult male Sprague-Dawley rats were randomized to undergo intratracheal instillation of (a) $5 \times 10^{9}$ adenoassociated virus (AAV) vectors encoding the $\mid \kappa B \alpha$ transgene $\left(5 \times 10^{9} \mathrm{AAV}-\mathrm{I} \kappa \mathrm{B} \alpha\right)$; (b) $1 \times 10^{10} \mathrm{AAV}-\mathrm{l} \kappa \mathrm{B} \alpha$; (c) $5 \times 10^{10} \mathrm{AAV}-\mathrm{I} \kappa \mathrm{B} \alpha$; or (d) vehicle alone. After intratracheal inoculation with Escherichia coli, the severity of the lung injury was measured in one series over a 4-hour period (acute pneumonia), and in a second series after 72 hours (prolonged pneumonia). Additional experiments examined the effects of $\mid \kappa B \alpha$ and null-gene overexpression on E. coli-induced and sham pneumonia.
\end{abstract}

Results: In acute pneumonia, $\mid \kappa B \alpha$ dose-dependently decreased lung injury, improving arterial oxygenation and lung static compliance, reducing alveolar protein leak and histologic injury, and decreasing alveolar IL-1 $\beta$ concentrations. Benefit was maximal at the intermediate $\left(1 \times 10^{10}\right) \mid \kappa B \alpha$ vector dose; however, efficacy was diminished at the higher $\left(5 \times 10^{10}\right) \mid \kappa B \alpha$ vector dose. In contrast, $\mid \kappa B \alpha$ worsened prolonged pneumonia-induced lung injury, increased lung bacterial load, decreased lung compliance, and delayed resolution of the acute inflammatory response.

Conclusions: Inhibition of pulmonary NF- $\kappa$ B activity reduces early pneumonia-induced injury, but worsens injury and bacterial load during prolonged pneumonia.

Keywords: Acute lung injury, inhibitory kappa-B alpha, rat, acute respiratory distress syndrome, bacteria, pneumonia, gene therapy

\section{Introduction}

Acute lung injury (ALI) and acute respiratory distress syndrome (ARDS) are life-threatening disorders, for which no specific therapy is known. When ARDS occurs in the setting of multisystem organ failure, mortality rates more than $60 \%$ have been reported, with significant morbidity in $50 \%$ of survivors [1]. ALI and ARDS develop most commonly in the context of severe sepsis

\footnotetext{
* Correspondence: laffeyj@smh.ca

1 Regenerative Medicine Institute, National University of Ireland Galway, University Road, Newcastle, Galway, Ireland

Full list of author information is available at the end of the article
}

[2], particularly infection with gram-negative bacilli such as Escherichia coli (E. coli) [3], and sepsis-induced ARDS has the worst outcome [4].

Nuclear factor kappa B (NF- $\kappa \mathrm{B})$ is a key transcriptional regulator in the setting of inflammation and injury and plays a role in diverse inflammatory disorders, including acute lung injury [5]. Activation of NF- $\kappa \mathrm{B}$ occurs in response to diverse stimuli, such as endotoxin, which bind to cell-surface receptors that in turn activate the canonic and/or noncanonic signaling pathway. This signaling cascade ultimately results in the phosphorylation and inactivation of the cytosolic inhibitor $\mathrm{I} \kappa \mathrm{B}$ complex, which then 
dissociates, allowing NF- $\kappa \mathrm{B}$ to translocate to the nucleus to initiate gene transcription [5]. Inhibition of NF- $\kappa \mathrm{B}$ reduces injury in preclinical models of ALI, including ischemia-reperfusion [6], endotoxemia [7], and cecal ligation and puncture-induced sepsis [8]. However, NF- $\kappa \mathrm{B}$ also exerts important cytoprotective effects, promoting cell survival, resolution of inflammation, and wound repair [9]. Of interest, NF- $\kappa \mathrm{B}$ signaling plays a central role in the host response to lung bacterial infection [10]. Consequently, inhibition of NF- $\kappa$ B may constitute a doubleedged sword, particularly in pneumonia-induced ALI/ ARDS, in which immune competence is essential to eradication of the infectious agent [11].

We wished to determine the potential for inhibition of pulmonary NF- $\kappa$ B activity to modulate the severity of pneumonia-induced lung injury. We used a gene-based therapy approach, via intrapulmonary delivery of three different doses of adenoassociated viral vector encoding the $\mathrm{NF}-\kappa \mathrm{B}$ inhibitor $I \kappa B \alpha$ gene (AAV-I $\kappa \mathrm{B} \alpha$ ), to modulate the NF- $\kappa$ B signaling pathway in the lung. We hypothesized that pulmonary overexpression of the NF- $\kappa \mathrm{B}$ inhibitor $\mathrm{I} \kappa \mathrm{B} \alpha$ would (a) attenuate the severity of the lung injury induced by acute $E$. coli pneumonia; but would (b) worsen the severity of prolonged $E$. coli pneumonia-induced lung injury; and (c) a dose-response relation would exist, with higher $\mathrm{AAV}-\mathrm{I} \kappa \mathrm{B} \alpha$ doses having the greatest effect.

\section{Materials and methods}

Specific-pathogen-free adult male Sprague-Dawley rats (350 to $450 \mathrm{~g}$ ) were used in all studies. The experimental model was based on those previously reported [12-14]. All work was approved by the National University of Ireland Galway Research Ethics Committee and conducted under license from the Department of Health, Ireland.

\section{Preparation of AAV vectors}

AAV-vector production was carried out as previously described, with several modifications [15]. The $I \kappa B \alpha-$ SuperRepressor $(I \kappa B \alpha-S R)$ gene (1,566 bp) was ligated into the pAAV-MCS vector (Agilent Technologies Inc., Santa Clara, CA, USA), and plasmid size confirmed by gel electrophoresis and validated by sequencing (Eurofins MWG Operon, Ebersberg, Germany). The I $\kappa B \alpha$-FLAG plasmid DNA and AAV serotype 6 envelope were generated and sent to Virapur for AAV production (VIRAPUR, 6160 Lusk Blvd., Suite C-101, San Diego, CA, USA). AAV serotype 6 was chosen because AAV has reduced immunogenicity, the virus plasmid size is sufficient for the $I \kappa B \alpha$-SuperRepressor (I $\kappa B \alpha$-SR) gene, and serotype 6 has demonstrated tropism for lung epithelial cells.

Viral vector particle titers were determined with quantitative real-time polymerase chain reaction (qRT-PCR) and aliquoted and stored at $-80^{\circ} \mathrm{C}$. As required, an aliquot was thawed and added to $75 \mu \mathrm{l}$ of the porcine surfactant Curosurf $(120 \mathrm{mg} / \mathrm{ml})$ (Trinity-Chiesi Pharmaceuticals Limited, Cheadle, UK), and a final instillate volume of $300 \mu \mathrm{l}$ was made up with PBS. For those animals receiving vehicle only, the instillate was $75 \mu \mathrm{l}$ of Curosurf mixed with $225 \mu$ of phosphate-buffered saline (PBS). Curosurf surfactant was added to each instillate, as it was demonstrated in prior studies to enhance spread and improve transgene expression [16].

\section{Acute and prolonged $E$. coli-induced lung injury Experimental design}

Animals were randomized to intratracheal instillation of the following: (a) vehicle alone; (b) $5 \times 10^{9} \mathrm{drp} \mathrm{AAV}$ $I \kappa B \alpha-S R$; (c) $1 \times 10^{10} \mathrm{drp}$ AAV I $\kappa B \alpha-S R$; or (d) $5 \times 10^{10}$ drp AAV I $\kappa B \alpha-S R$, and to undergo subsequent acute (Series 1) or prolonged (Series 2) pneumonia-induced ALI. Additional experimental series examined the effects of $1 \times 10^{10} \mathrm{AAV}-\mathrm{I} \kappa B \alpha$ versus $1 \times 10^{10} \mathrm{AAV}$-Null in both acute and prolonged $E$. coli and sham pneumonia.

\section{Vector instillation}

Animals were anesthetized by inhalational induction with isoflurane and an intraperitoneal injection of $40 \mathrm{mg} / \mathrm{kg}$ ketamine (Pfizer, Kent, UK). After confirmation of depth of anesthesia, laryngoscopy was performed (Welch Allyn Otoscope; Buckinghamshire, UK), and the trachea intubated with a size 16 intravenous catheter (BD Insyte; Becton Dickinson Ltd., Oxford, UK). After instillation of vector or vehicle, depending on the specific series, animals were extubated and allowed to recover from anesthesia.

\section{E. coli/vehicle instillation}

The E. coli used in these experiments is E5162 (serotype: O9 K30 H10) and was supplied by the National Collection of Type Cultures, Central Public Health Laboratory, London, England. The E. coli were stored on preservative beads (Protect, Lancashire, England) at $-80^{\circ} \mathrm{C}$. Beads were placed in 3-ml vials of peptone water (Cruinn Diagnostics, Dublin, Ireland) and incubated at $37^{\circ} \mathrm{C}$ for 18 to 24 hours to allow bacterial concentrations to reach a plateau. The bacterial suspension was then centrifuged and washed in phosphate-buffered saline to produce the inoculum. The bacterial load in each inoculum was determined by plating serial dilutions on agar plates. Preliminary experiments were performed to determine the bacterial load of intratracheal E. coli required to produce a lung injury over a 4-hour and over a 72-hour period.

\section{Acute pneumonia protocol}

Ninety-six hours after virus instillation, animals were anesthetized with intraperitoneal $80 \mathrm{mg} / \mathrm{kg}$ ketamine and $8 \mathrm{mg} / \mathrm{kg}$ xylazine, and anesthesia maintained with Alfaxalone (Alfaxadone $0.9 \%$ and alfadadolone acetate $0.3 \%$ ). A tracheostomy tube was inserted, and intraarterial access was sited in the carotid artery. Muscle relaxation was induced with cisatracurium besylate, and the lungs were mechanically ventilated with $30 \% \mathrm{O}_{2}$ in $70 \% \mathrm{~N}_{2}$. After 
20 minutes, arterial blood gas measurement was performed and $1 \times 10^{11}$ E. coli in a 300- $\mu$ l PBS suspension (or vehicle alone) instilled via the tracheostomy $[12,13]$. Animals were ventilated for 4 hours, with systemic arterial blood pressure, peak airway pressure, and body temperature continually measured. Lung compliance and arterial blood gas analysis was measured hourly, and body temperature was maintained at $36^{\circ} \mathrm{C}$ to $37.5^{\circ} \mathrm{C}$.

\section{Prolonged pneumonia protocol}

Animals were anesthetized by inhalational induction with isoflurane and intraperitoneal $40-\mathrm{mg} / \mathrm{kg}$ ketamine (Pfizer, Kent, UK). After confirmation of anesthesia depth, $5 \times 10^{9}$ E. coli in a 300- $\mu$ l PBS suspension was instilled into the trachea under direct vision, and the animals allowed to recover [17]. Animals were monitored closely for 72 hours after E. coli instillation, and then reanesthetized, tracheostomized, and mechanical ventilation was instituted, and injury severity assessed, as described [18].

\section{Postmortem analyses}

At the end of the protocols, the animals were killed by exsanguination under anesthesia, and the plasma snapfrozen for later analysis. The heart-lung block was dissected from the thorax, bronchoalveolar lavage (BAL) was performed, and BAL fluid differential leukocyte counts and lung bacterial colony counts were completed. BAL fluid was centrifuged, and the supernatant was snap-frozen and stored at $-80^{\circ} \mathrm{C}$. BAL concentrations of IL-1 $\beta$, TNF-a, IL-6, CINC-1, IL-10, and KGF were determined by using ELISA (R\&D Systems, Abingdon, UK), and BAL protein concentrations were measured (Micro BCA Protein assay kit; Pierce, Rockford, IL, USA) [16]. The left lung was isolated and fixed, and the extent of histologic lung damage determined by using quantitative stereologic techniques [18].

\section{Assessment of transgene expression and efficacy}

$I \kappa B \alpha-F L A G$ transgene expression was determined in lung homogenates with real-time PCR and Western blotting, as previously described [16,19]. In brief, RNA was extracted from lung tissue, cDNA was synthesised, and quantitative PCR was performed for $I \kappa B \alpha-F L A G$, normalized against a GAPDH control product. For Western blot I $\kappa \mathrm{B} \alpha$-FLAG analysis, total cell protein was extracted, protein concentration was determined, and samples were electrophoresed on an SDS-PAGE gel and transferred to nitrocellulose [20]. Primary anti-human I $\kappa \mathrm{B} \alpha$-FLAG monoclonal antibody (Sigma-Aldrich, St. Louis, MO, USA) was used, with secondary antibody conjugated to horseradish peroxidase (Cell Signaling Technology, Danvers, MA, USA), and the membrane incubated with a chemiluminescent substrate (SuperSignal West Pico; Pierce).
The effect of $I \kappa B \alpha$ overexpression on the activation of the NF- $\kappa \mathrm{B}$ pathway was assessed by measurement of nuclear accumulation of the activated P65 subunit of NF- $\kappa$ B [19]. Nuclear extracts were performed on homogenized rat lung tissue by using a NE-PER Nuclear and Cytoplasmic Extraction Kit (Fisher Scientific Ireland, Dublin, Ireland), and NF- $\kappa$ B (p65) measured by using an NF- $\kappa$ B Transcription Factor Assay Kit (Cayman Chemical Company, Ann Arbor, MI, USA).

\section{Data presentation and analysis}

Continuous responsive variables are summarized by using mean (SD) and median (interquartile range, IQR) as necessary. The proportion of animals surviving was analyzed by using the $\chi^{2}$ test. All other data were analyzed with one-way ANOVA, followed by the Dunnett test or by Kruskal-Wallis, followed by the Dunn test, with the vehicle group used as the reference group for all comparisons. The assumptions underlying all models were checked by using suitable residual plots. A $P$ value of $<0.05$ was considered statistically significant.

\section{Results}

\section{Acute pneumonia-induced ALI}

Sixty-eight animals were entered into these experimental series. In the first set of experiments, 48 animals were randomized to receive (a) vehicle alone $(n=12)$; (b) $5 \times$ $10^{9}$ AAV-I $\left.\kappa \mathrm{B} \alpha n=12\right)$; (c) $1 \times 10^{10}$ AAV-I $\kappa \mathrm{B} \alpha(n=$ 12); (d) $5 \times 10^{10} \mathrm{AAV}-\mathrm{I} \kappa \mathrm{B} \alpha(n=12)$, and all animals subsequently underwent intratracheal $E$. coli instillation. No differences were noted between the groups at baseline (Table 1).

$\mathrm{I} \kappa \mathrm{B} \alpha$ expression and function Pulmonary instillation of $A A V-I \kappa B \alpha$ produced a dose-dependent increase in lung $I \kappa B \alpha$ gene transcription (Figure $1 \mathrm{~A}$ ) and protein production (Figure $1 \mathrm{~B}, \mathrm{C})$. Densitometry of $\mathrm{I} \kappa \mathrm{B} \alpha$-FLAG Western blot ( $n=3$ per group) confirmed this dosedependent increase in $\mathrm{I} \kappa \mathrm{B} \alpha$ protein (Figure $1 \mathrm{C}$ ). I $\kappa B \alpha$ overexpression decreased $E$. coli-induced NF- $\kappa \mathrm{B}$ activation, as measured by nuclear accumulation of the activated P65 subunit of NF- $\kappa$ B (Figure 1D).

Survival and bacterial load $\mathrm{I} \kappa \mathrm{B} \alpha$ overexpression enhanced animal survival, with survival rates of $33 \%$ in the Vehicle group, $58 \%$ with $5 \times 10^{9} I \kappa B \alpha$, and $92 \%$ with $1 \times 10^{10} I \kappa B \alpha$ Of concern, the highest $I \kappa B \alpha(5 \times$ $10^{10}$ ) dose abolished the survival benefit (Table 1). I $\kappa \alpha \alpha$ overexpression also enhanced the duration of animal survival, which followed this same pattern, with the effect greatest with the $1 \times 10^{10} I \kappa B \alpha$ dose (Table 1). Importantly, $\mathrm{I} \kappa \mathrm{B} \alpha$ did not alter lung bacterial loads (Table 1).

\section{$I \kappa B \alpha$ modulated lung-injury severity}

The E. coli instillation induced a severe acute lung injury (Figure 2). $I \kappa B \alpha$ overexpression reduced the 
Table 1 Data regarding animals subjected to acute pneumonia-induced ALI

\begin{tabular}{|c|c|c|c|c|}
\hline Variable & Vehicle & $5 \times 10^{9} \mathrm{I} \kappa \mathrm{B} \alpha$ & $1 \times 10^{10} \mathrm{I} \kappa \mathrm{B} \alpha$ & $5 \times 10^{10} \mathrm{I} \kappa \mathrm{B} \alpha$ \\
\hline Number of animals & 12 & 12 & 12 & 12 \\
\hline Animal weight (g) & $456 \pm 55$ & $486 \pm 54$ & $469 \pm 52$ & $438 \pm 86$ \\
\hline Bacteria instilled $\left(\mathrm{CFU} \times 10^{10}\right)$ & $1.1 \pm 0.2$ & $2.1 \pm 0.2$ & $2.6 \pm 2.0$ & $2.1 \pm 2.2$ \\
\hline Baseline arterial $\mathrm{PO}_{2}(\mathrm{kPa})$ & $18.7 \pm 0.5$ & $18.7 \pm 0.8$ & $18.8 \pm 0.8$ & $18.7 \pm 0.8$ \\
\hline Baseline static compliance $(\mathrm{ml} / \mathrm{mm} \mathrm{Hg})$ & $0.93 \pm 0.1$ & $0.95 \pm 0.1$ & $0.99 \pm 0.2$ & $0.87 \pm 0.2$ \\
\hline Animal survival (number, \%) & $4(33)$ & $7(58)$ & $11(92)^{*}$ & $5(42)$ \\
\hline Duration of animal survival (hours) & $2.75(2,4)$ & $4(1.5,4)$ & $4(4,4)^{*}$ & $3(1.75,4)$ \\
\hline Lung homogenate bacterial counts (CFU $\times 10^{9}$ ) & $0.8(0.4,1.7)$ & $1.4(0.2,2.6)$ & $0.6(0.4,0.9)$ & $0.7(0.4,0.9)$ \\
\hline BAL neutrophils $\left(\times 10^{7} / \mathrm{ml}\right)$ & $5.9(1.5,8.4)$ & $3.7(1.5,8.9)$ & $6.2(1.8,6.7)$ & $8.5(1.1,9.1)$ \\
\hline BAL mononuclear cells $\left(\times 10^{7} / \mathrm{ml}\right)$ & $2.2(1.4,9.1)$ & $0.57(2.7,7.0)$ & $1.5(1.2,9.3)$ & $1.8(1.1,9.6)$ \\
\hline
\end{tabular}

Note: Data are expressed as mean \pm SD. *Significantly different from Vehicle group.

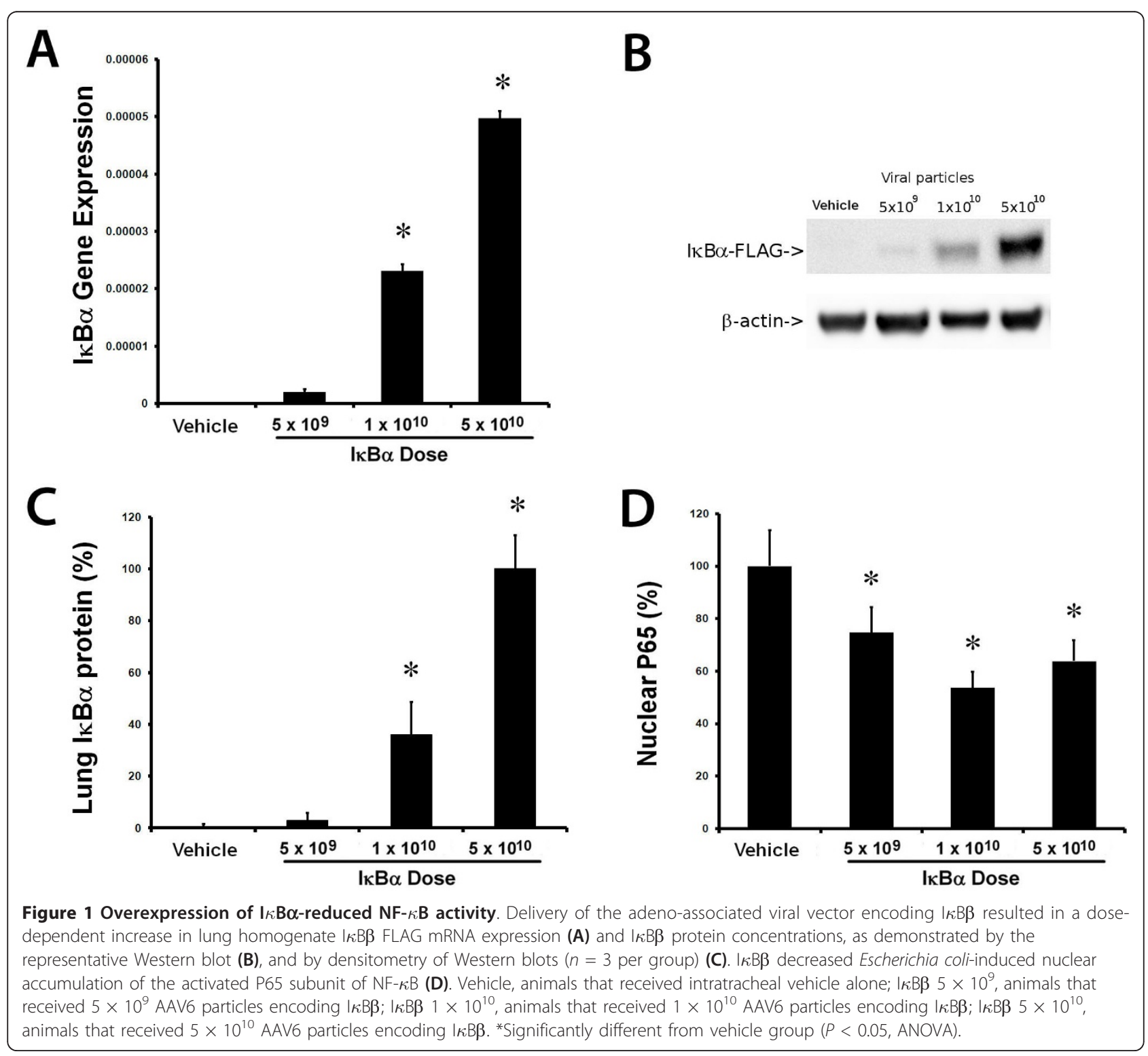




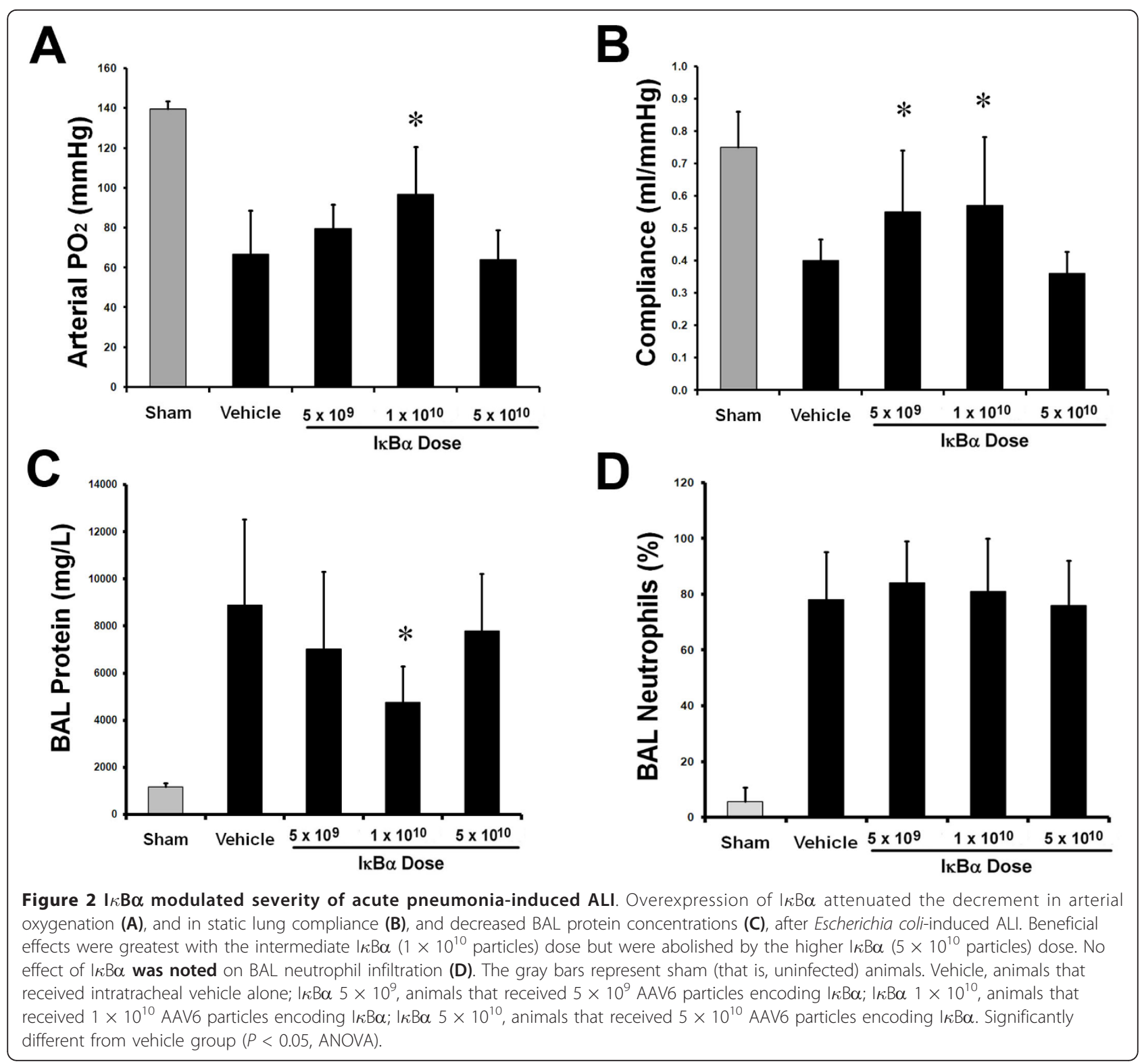

E. coli-induced decrement in arterial oxygenation, with benefit greatest at intermediate $\left(1 \times 10^{10}\right) I \kappa B \alpha$ vector dose, but abolished at the higher $\left(5 \times 10^{10}\right) I \kappa B \alpha$ dose (Figure 2A and Table 1). A similar pattern was seen with regard to the decrement in static compliance (Figure 2B), and pulmonary permeability, as assessed by protein leak into the BAL fluid (Figure 2C), but no effect was seen in regard to BAL neutrophil or mononuclear cell counts (Figure $2 \mathrm{D}$ and Table 1). I $B \mathrm{~B} \alpha$ reduced $E$. coli-induced histologic evidence of lung injury, with the intermediate $\left(1 \times 10^{10}\right)$ vector dose of $I \kappa B \alpha$ again most effective (Figure 3A through $\mathrm{E}$ ).

\section{$I \kappa B \alpha$ modulates pulmonary inflammation}

The E. coli instillation activated the inflammatory response. $I \kappa B \alpha$ significantly decreased alveolar IL-1 $\beta$, but did not alter BAL TNF- $\alpha$ or interleukin- 6 concentrations (Figure 4A through $\mathrm{C}$ ). $I \kappa B \alpha$ dose-dependently modulated BAL CINC-1 and KGF, but did not alter BAL IL-10 concentrations (Figure 4D, F).

\section{Sham acute pneumonia and null-transgene series}

Additional experiments were performed to determine the effect of overexpression of a null transgene (versus vehicle; $n=4$ per group) on the severity of $E$. coli pneumonia, and to determine the effect of $I \kappa B \alpha$ and null-gene overexpression in sham pneumonia (versus vehicle; $n=4$ per group). In these studies, the null transgene did not alter the severity of $E$. coli-induced lung injury (Table 2). In addition, overexpression the null or $I \kappa B \alpha$ transgenes in shaminjured animals did not alter lung function (Table 3). 


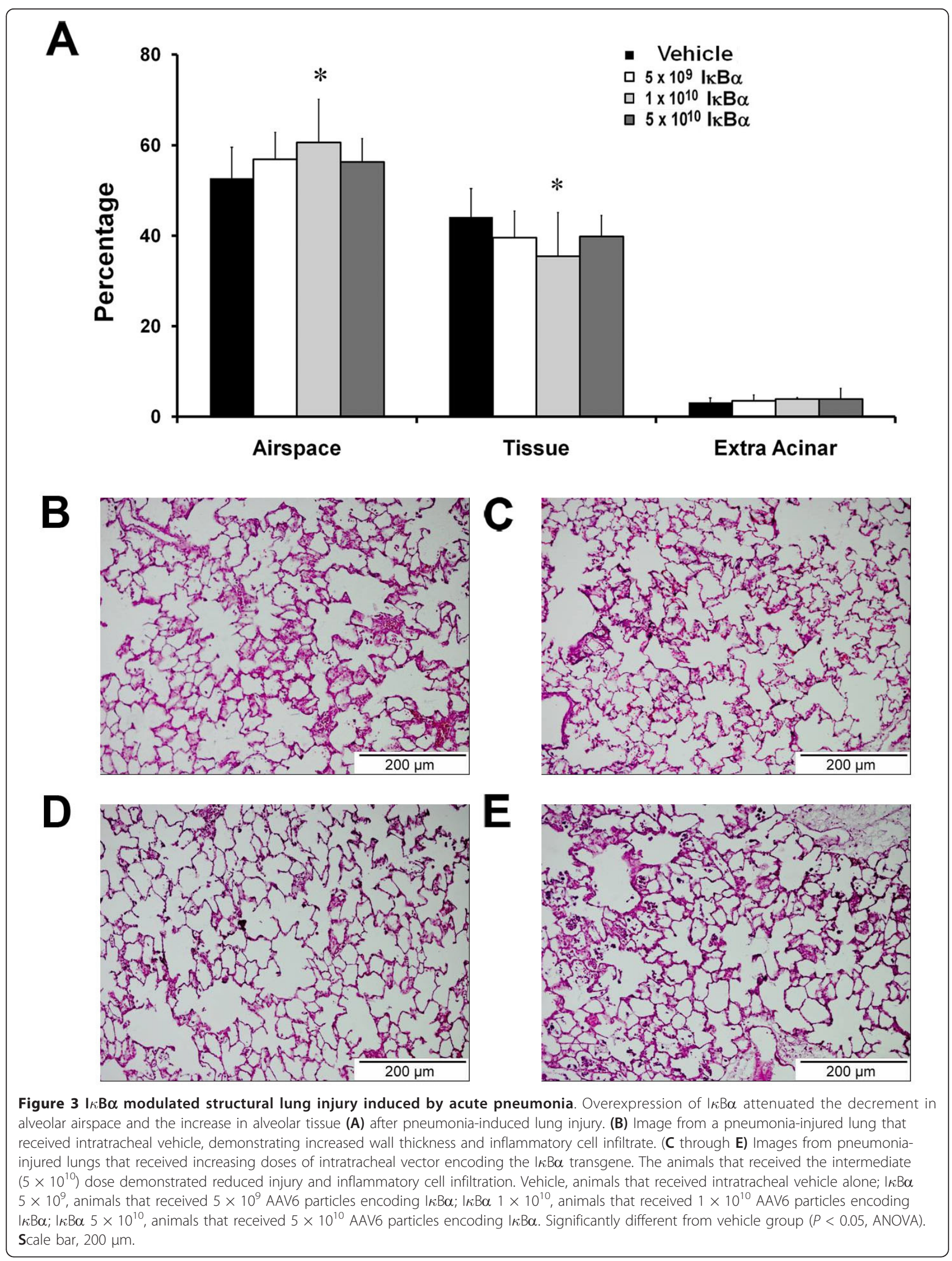



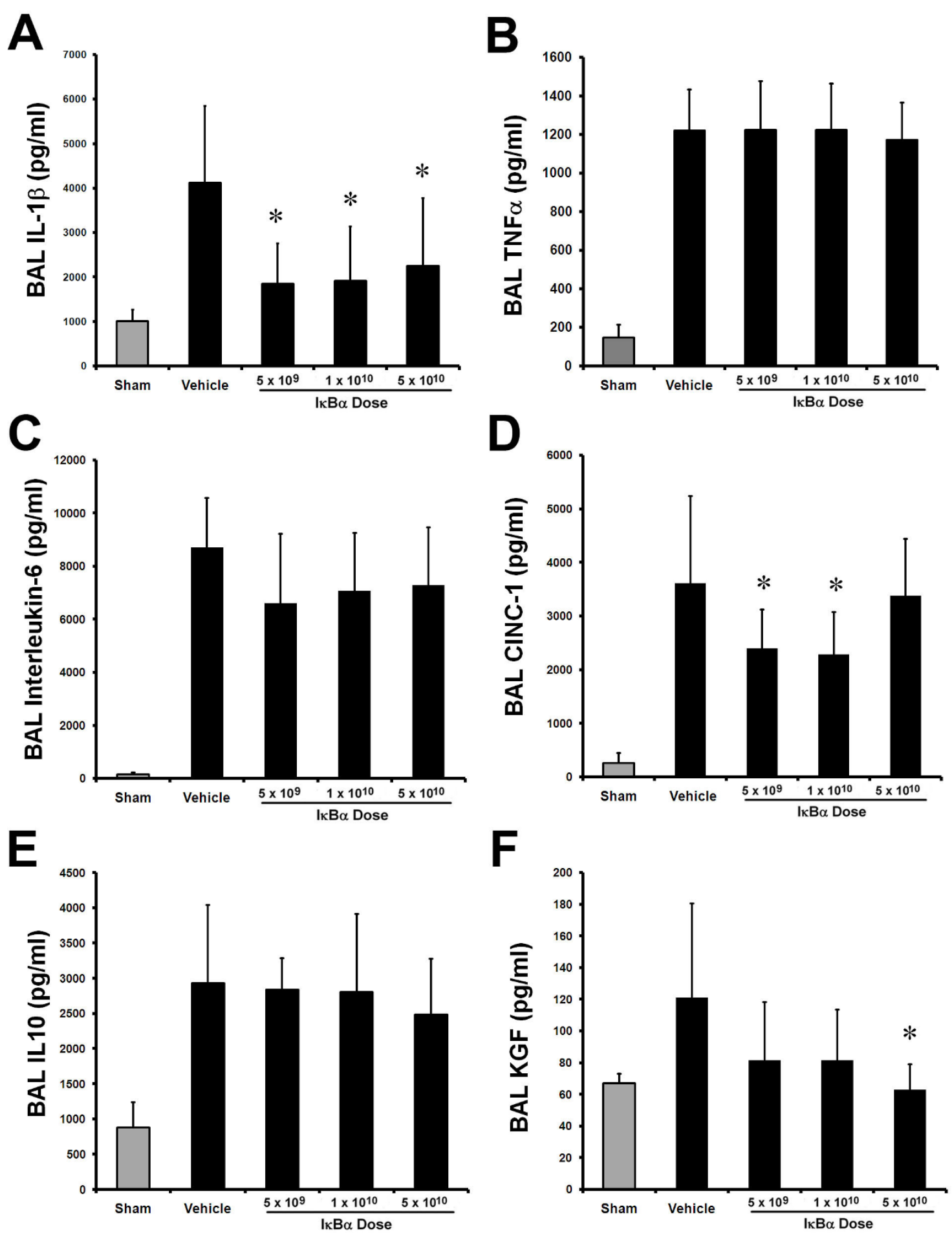

Figure $4 \mathrm{I} \kappa \mathrm{B} \alpha$ dose-dependently modulated the inflammatory response to acute pneumonia-induced $\mathrm{ALI}$. Overexpression of $\mid \kappa B \alpha$ attenuated the increase in BAL interleukin-1 $\beta$ (A), but did not alter BAL TNF- $\alpha$ (B), or interleukin-6 concentrations (C), after Escherichia coliinduced ALI. I $\kappa B \alpha$ dose dependently decreased BAL CINC-1 (D), did not alter BAL IL-10 concentrations (E), and dose dependently decreased BAL KGF concentrations $(\mathbf{F})$. These effects were greatest with the highest $\mid \kappa B \alpha\left(5 \times 10^{10}\right.$ particles) dose. The gray bars represent sham (uninfected) animals. Vehicle, animals that received intratracheal vehicle alone; $\mid \kappa B \alpha 5 \times 10^{9}$, animals that received $5 \times 10^{9}$ AAV 6 particles encoding $\mid \kappa B \alpha$; $\mid \kappa B \alpha 1 \times 10^{10}$, animals that received $1 \times 10^{10}$ AAV6 particles encoding $|\kappa B \alpha ;| \kappa B \alpha 5 \times 10^{10}$, animals that received $5 \times 1010^{9}$ AAV 6 particles encoding $\mid \kappa B \alpha, B A L$, bronchoalveolar lavage; IL-1 $\beta$, interleukin-1 $\beta$; TNF- $\alpha$, tumor necrosis factor- $\alpha$; CINC-1, cytokine-induced neutrophil chemoattractant-1; KGF, keratinocyte growth factor. Significantly different from vehicle group $(P<0.05$, ANOVA). 
Table 2 Overexpression of Null transgene does not modulate the severity of acute pneumonia-induced ALI

\begin{tabular}{lll}
\hline Variable & E. coli + vehicle & E. coli + null transgene \\
\hline Number of animals & 4 & 4 \\
\hline Animal weight $(\mathrm{g})$ & $443 \pm 25$ & $462 \pm 33$ \\
\hline Bacteria instilled $\left(\mathrm{CFU} \times 10^{10}\right)$ & $1.1(0.9,1.2)$ & $1.2(0.5,3.6)$ \\
\hline Animal survival $(n, \%)$ & $2(50 \%)$ & $2(50 \%)$ \\
\hline Duration of animal survival (hours) & $3.5(2,4)$ & $3.75(2.5,4)$ \\
\hline Lung homogenate bacterial counts $\left(\mathrm{CFU} \times 10^{9}\right)$ & $1.7(1.4,3.8)$ & $2.2(1.2,3.7)$ \\
\hline Final arterial $\mathrm{PO}(\mathrm{kPa})$ & $10.8 \pm 0.8$ & $9.3 \pm 1.2$ \\
\hline Final static compliance $(\mathrm{ml} / \mathrm{mm} \mathrm{Hg})$ & $0.39 \pm 0.1$ & $0.39 \pm 0.1$ \\
\hline BAL protein $(\mathrm{mg} / \mathrm{L})$ & $7,203(5,319,7,646)$ & $5,542(2,994,8,554)$ \\
\hline BAL neutrophils $\left(\times 10^{7} / \mathrm{ml}\right)$ & $3.8(2.1,5.2)$ & $8.1(4.6,11.2)$ \\
\hline BAL mononuclear cells $\left(\times 10^{7} / \mathrm{ml}\right)$ & $0.88(0.13,0.72)$ & $1.2(0.18,2.0)$
\end{tabular}

Data are expressed as mean \pm SD or median (interquartile range). Final data are data collected on completion of the experimental protocol. *Significantly different from Vehicle group. BAL, bronchoalveolar lavage; CFU, colony-forming unit.

\section{Prolonged pneumonia-induced ALI}

Fifty-six animals were entered into these experimental series. In the first set of experiments, 44 animals were randomized to receive (a) vehicle $(n=11)$; (b) $5 \times 10^{9}$ $\mathrm{AAV}-\mathrm{I} \kappa \mathrm{B} \alpha(n=11)$; (c) $1 \times 10^{10} \mathrm{AAV}-\mathrm{I} \kappa \mathrm{B} \alpha(n=11)$; (d) $5 \times 10^{10} \mathrm{AAV}-\mathrm{I} \kappa \mathrm{B} \alpha(n=11)$, and underwent prolonged $E$. coli-induced lung injury. No differences were found between the groups at baseline (Table 4).

\section{Animal Survival and Bacterial Load}

$\mathrm{I} \kappa \mathrm{B} \alpha$ did not alter the number or duration of animal survival (Table 4). However, $\mathrm{I} \kappa \mathrm{B} \alpha$ substantially increased lung E. coli bacterial loads at all three $\mathrm{I} \kappa \mathrm{B} \alpha$ doses (Table 4).

\section{$I \kappa B \alpha$ worsens lung injury}

E. coli instillation induced a severe lung injury compared with sham pneumonia (Figure 5 ). I $\kappa \mathrm{B} \alpha$ overexpression did not alter the decrement in arterial oxygenation (Figure $5 \mathrm{~A}$ ). I $\kappa \mathrm{B} \alpha$ overexpression dose dependently worsened static lung compliance (Figure $5 \mathrm{~B})$. I $\kappa \mathrm{B} \alpha$ did not alter alveolar protein leak (Figure $5 \mathrm{C}$ ), but did increase the proportion of neutrophils in the alveolar infiltrate
(Figure 5D), while decreasing alveolar mononuclear cells (Table 4$)$. I $\kappa \mathrm{B} \alpha$ worsened $E$. coli-induced histologic injury, with the intermediate $\left(1 \times 10^{10}\right)$ and higher $(5 \times$ $10^{10}$ ) dose of $\mathrm{I} \kappa \mathrm{B} \alpha$, resulting in significantly greater injury (Figure 6A through $\mathrm{E}$ ).

\section{$I \kappa B \alpha$ modulates pulmonary inflammation}

Prolonged E. coli pneumonia activated the inflammatory response compared with sham pneumonia (Figure 7). $\mathrm{I} \kappa \mathrm{B} \alpha$ overexpression dose-dependently increased alveolar IL-1 $\beta$ (Figure 7A) and TNF- $\alpha$ (Figure 7B), with concentrations highest after $5 \times 10^{10} \mathrm{I} \kappa \mathrm{B} \alpha$. In contrast, no effect was seen on alveolar IL-6 (Figure 7C) or CINC-1 (Figure 7D) concentrations. I $\kappa \mathrm{B} \alpha$ increased alveolar IL10 (Figure 7E) and KGF concentrations, with a step-wise dose effect seen (Figure 7F).

\section{Sham Prolonged Pneumonia}

In a subsequent experiment, 12 animals were randomized to receive: (a) Vehicle $(n=4)$; (b) $1 \times 10^{10} \mathrm{AAV}-\mathrm{Null}(n=$ 4); and (3) $1 \times 10^{10} \mathrm{AAV}-\mathrm{I} \kappa \mathrm{B} \alpha$ and to undergo subsequent

Table 3 Overexpression of Null or $\mathrm{I} \kappa \mathrm{B} \alpha$ transgenes does not alter lung function in animals subjected to sham pneumonia

\begin{tabular}{|c|c|c|c|}
\hline Variable & Vehicle & $\mathrm{I} \kappa \mathrm{B} \alpha$ transgene & Null transgene \\
\hline Number of animals & 4 & 4 & 4 \\
\hline Animal weight (g) & $413 \pm 30$ & $426 \pm 17$ & $427 \pm 19$ \\
\hline Animal survival (n, \%) & $4(100 \%)$ & $4(100 \%)$ & $4(100 \%)$ \\
\hline Duration of animal survival (hours) & $4[4,4]$ & $4[4,4]$ & $4[4,4]$ \\
\hline Final arterial $\mathrm{PO}_{2}(\mathrm{kPa})$ & $18.6 \pm 0.5$ & $18.4 \pm 1.1$ & $19.9 \pm 0.7$ \\
\hline Final static compliance $(\mathrm{ml} / \mathrm{mm} \mathrm{Hg})$ & $0.65 \pm 0.11$ & $0.71 \pm 0.17$ & $0.58 \pm 0.16$ \\
\hline $\mathrm{BAL}$ protein $(\mathrm{mg} / \mathrm{L})$ & $1197[1061,1296]$ & $1353[991,2167]$ & $1337[950,1869]$ \\
\hline BAL neutrophils $\left(\times 10^{4} / \mathrm{ml}\right)$ & $0.2[0.0,1.4]$ & $1.3[0.5,1.8]$ & $1.1[0.2,2.0]$ \\
\hline BAL mononuclear cells $\left(\times 10^{4} / \mathrm{ml}\right)$ & $21.0[11,22]$ & $23[10,29]$ & $14[12,18]$ \\
\hline
\end{tabular}

Data are expressed as mean \pm SD or median (interquartile range). Final data are data collected on completion of the experimental protocol. *Significantly different from Vehicle group. BAL, bronchoalveolar lavage; CFU, colony-forming units. 
Table 4 Data regarding animals subjected to prolonged pneumonia-induced ALI

\begin{tabular}{|c|c|c|c|c|}
\hline Variable & Vehicle & $5 \times 10^{9} \mathrm{I} \kappa \mathrm{B} \alpha$ & $1 \times 10^{10} I_{\kappa} \mathrm{B} \alpha$ & $5 \times 10^{10} \mathrm{I} \kappa \mathrm{B} \alpha$ \\
\hline Number of animals & 11 & 11 & 11 & 11 \\
\hline Animal weight (g) & $383 \pm 13$ & $378 \pm 19$ & $413 \pm 35$ & $401 \pm 47$ \\
\hline Animal survival (number, \%) & $8(73)$ & $9(82)$ & $9(82)$ & $8(73)$ \\
\hline Duration of animal survival (hours) & $65.5 \pm 11.2$ & $64.8 \pm 16.2$ & $63.3 \pm 19.4$ & $63.3 \pm 16.1$ \\
\hline Instilled E. coli bacterial load $\left(\right.$ CFU $\left.\times 10^{4}\right)$ & $5.0 \pm 1.0$ & $5.0 \pm 1.0$ & $5.0 \pm 1.0$ & $5.0 \pm 1.0$ \\
\hline Peak airway pressure $(\mathrm{mm} \mathrm{Hg})$ & $8.1 \pm 1.4$ & $6.5 \pm 1.0$ & $7.4 \pm 1.0$ & $8.0 \pm 1.3$ \\
\hline Lung homogenate bacterial counts $\left(\mathrm{CFU} \times 10^{4}\right.$ ) & $1.1(0.7,3.1)$ & $51.3(3.1,96)^{*}$ & $20.7(15.9,36.2)^{*}$ & $19.3(16.5,34.6)^{*}$ \\
\hline BAL neutrophils $\left(\times 10^{9} / \mathrm{ml}\right)$ & $3.7 \pm 3.3$ & $2.3 \pm 0.8$ & $3.8 \pm 2.2$ & $1.7 \pm 0.9$ \\
\hline BAL mononuclear cells $\left(\times 10^{9} / \mathrm{ml}\right)$ & $2.3 \pm 1.8$ & $0.4 \pm 0.2^{*}$ & $0.9 \pm 0.6^{*}$ & $0.4 \pm 0.2^{*}$ \\
\hline
\end{tabular}

Data are expressed as mean \pm SD or median (interquartile range). Final data are data collected on completion of the experimental protocol. ${ }^{*}$ Significantly different from Vehicle group. BAL, bronchoalveolar lavage; CFU, colony-forming units.

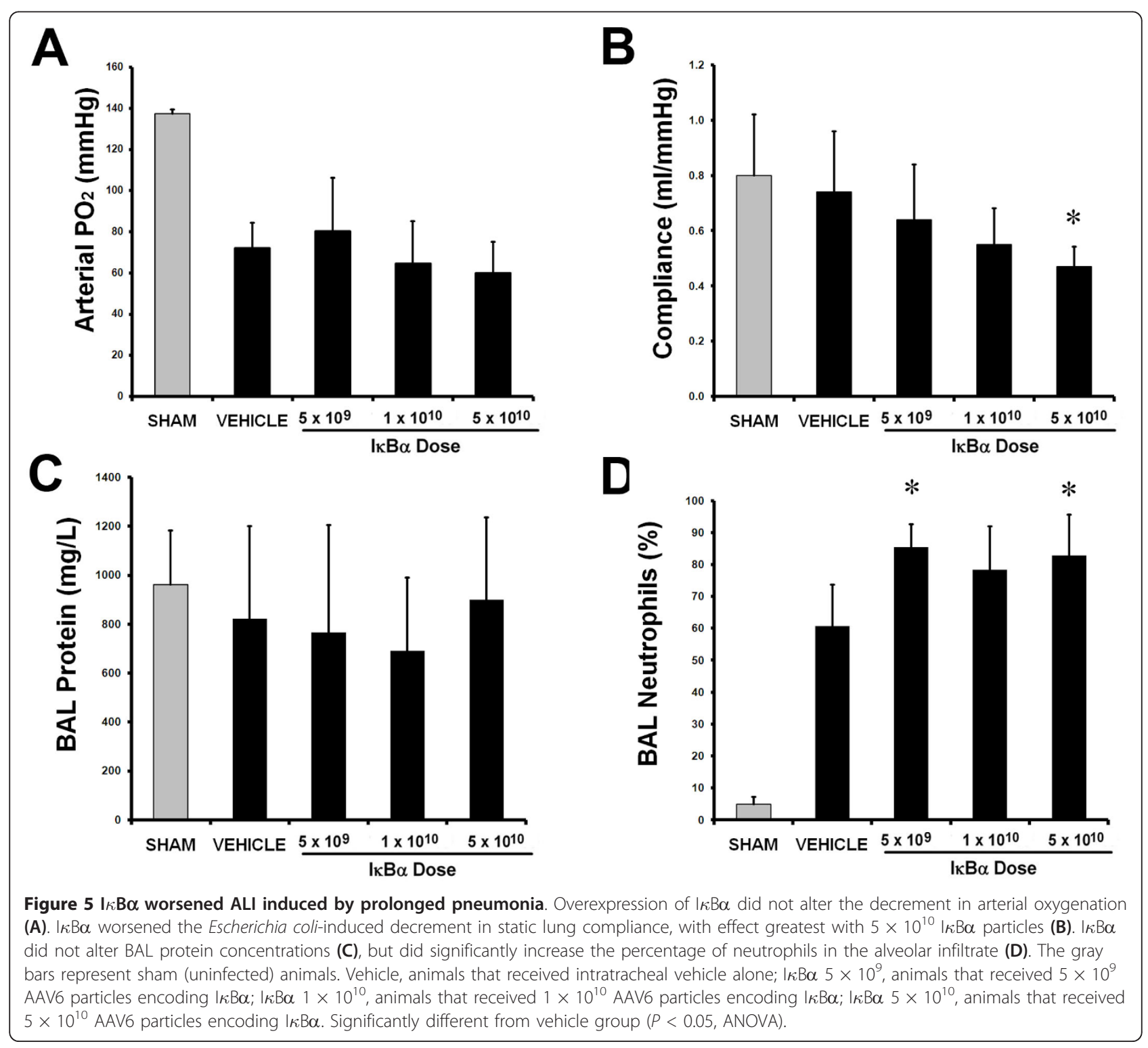




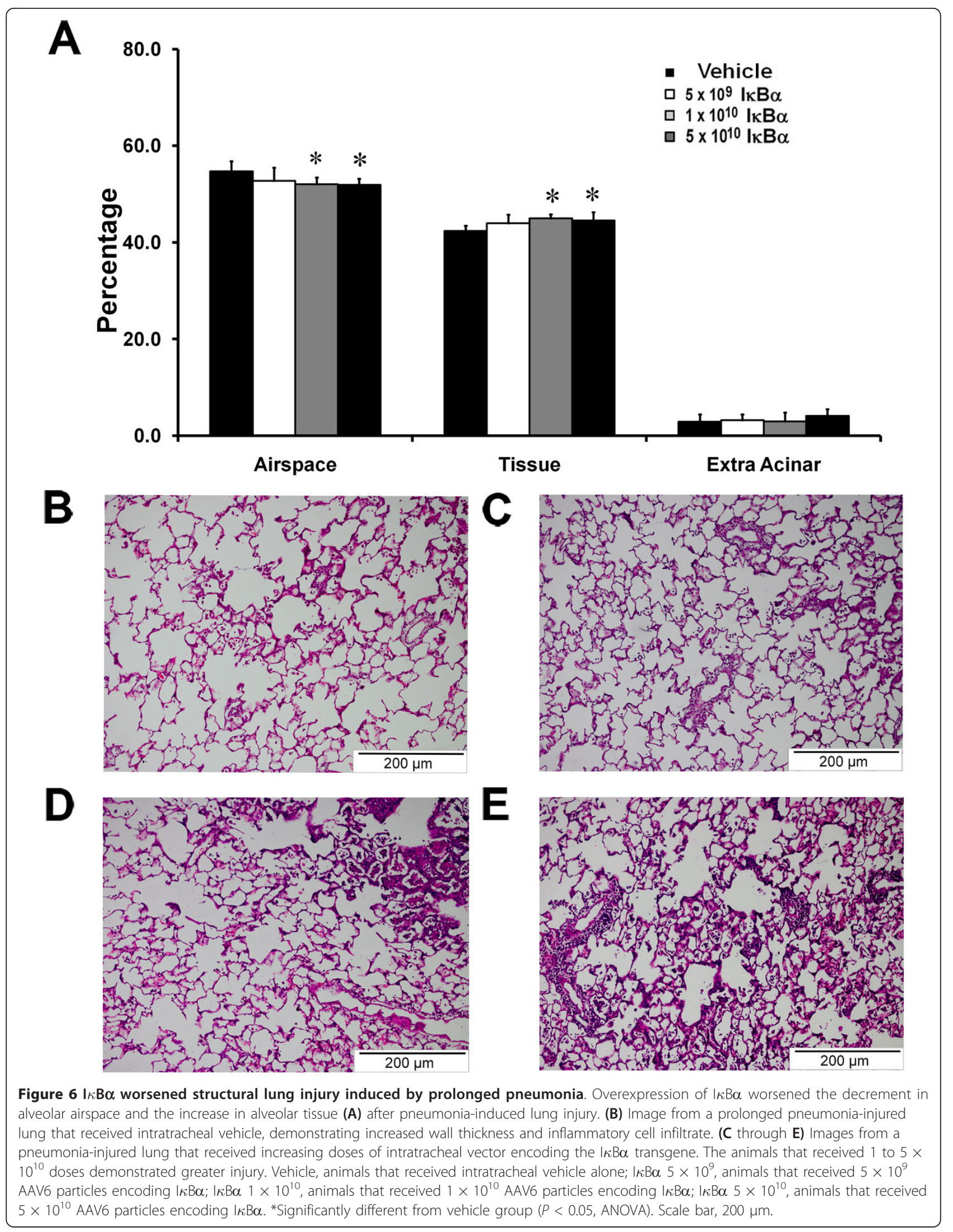



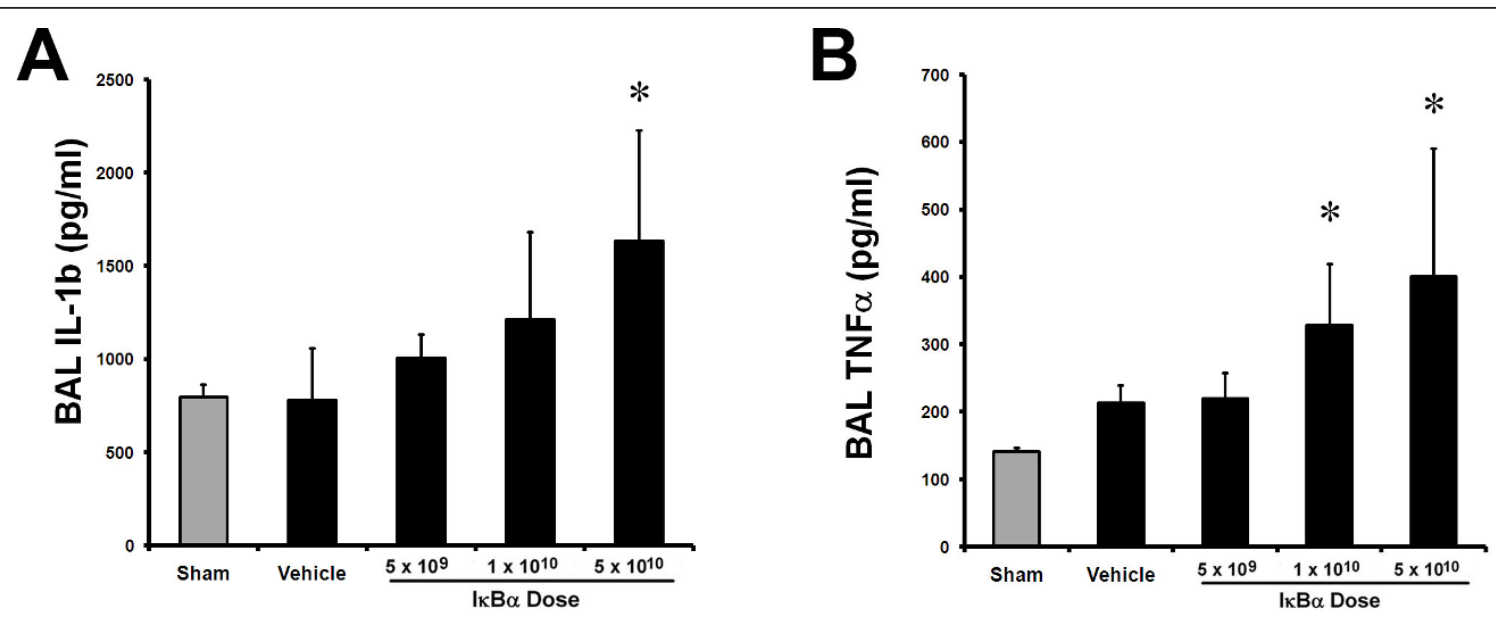

C.

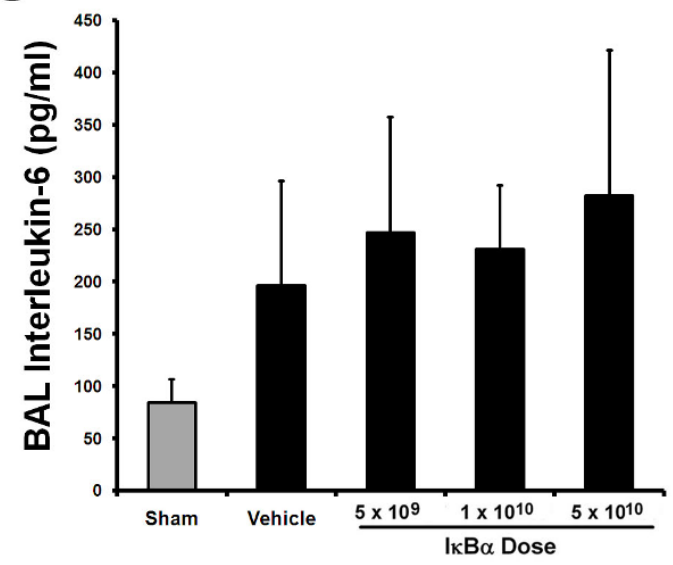

$\mathbf{E}$

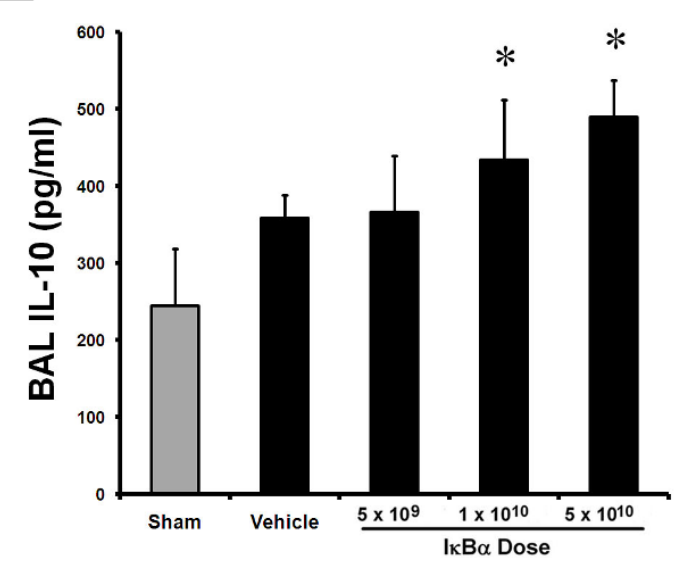

D

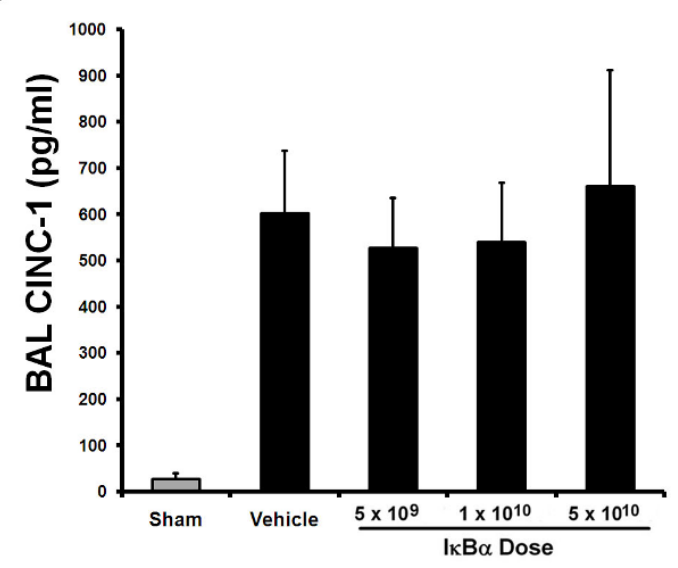

$\mathbf{F}$

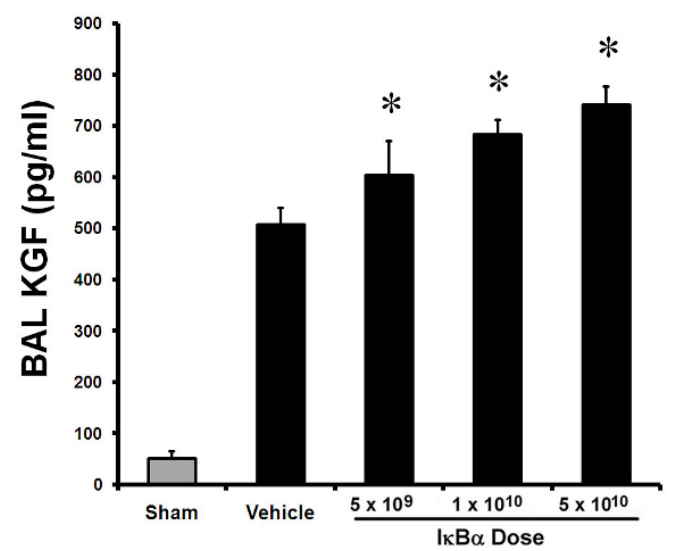

Figure $7 \mathrm{I} \kappa \mathrm{B} \alpha$ dose-dependently modulated the inflammatory response to prolonged pneumonia. Overexpression of $\mid \kappa B \alpha$ dosedependently increased BAL interleukin-1 $\beta$ (A) and TNF- $\alpha$ (B) concentrations compared with vehicle. No effect of $\mid \kappa B \alpha$ was seen on interleukin- 6 (C) or CINC-1 (D) concentrations. I $\kappa$ B $\alpha$ dose-dependently increased BAL IL-10 (E), and KGF concentrations (F). These effects were greatest with the highest $\mid \kappa \mathrm{B} \alpha\left(5 \times 10^{10}\right.$ particles) dose. The gray bars represent sham (uninfected) animals. Vehicle, animals that received intratracheal vehicle alone; $\mid \kappa \mathrm{B} \alpha 5 \times 10^{9}$, animals that received $5 \times 10^{9} \mathrm{AAV} 6$ particles encoding $|\kappa \mathrm{B} \alpha ;| \kappa \mathrm{B} \alpha 1 \times 10^{10}$, animals that received $1 \times 10^{10} \mathrm{AAV} 6$ particles encoding $|\kappa B \alpha ;| \kappa B \alpha 5 \times 10^{10}$, animals that received $5 \times 10^{10}$ AAV 6 particles encoding $\mid \kappa B \alpha$. ${ }^{*}$ Significantly different from vehicle group $(P<0.05$, ANOVA). 
sham (vehicle) instillation. The null or $\mathrm{I} \kappa \mathrm{B} \alpha$ transgenes did not alter lung function in sham infected animals (Table 5).

\section{Discussion}

Pulmonary overexpression of $\mathrm{I} \kappa \mathrm{B} \alpha$ attenuated acute pneumonia-induced lung injury, decreasing the severity of the decrement in lung function, whereas also decreasing the inflammatory response. In contrast, $\mathrm{I} \kappa \mathrm{B} \alpha$ worsened lung injury and inflammation induced by prolonged pneumonia, increasing lung bacterial load and delaying resolution of the inflammatory response. These findings provide novel insights into the effects of NF- $\kappa \mathrm{B}$ in pneumonia-induced lung injury, and raise concerns regarding therapeutic potential of inhibiting NF- $\kappa \mathrm{B}$, particularly in prolonged untreated pneumonia.

\section{E. coli acute and prolonged pneumonia}

Infection with gram-negative bacilli such as $E$. coli is the commonest cause of ARDS [21,22] and is also a very common complication of ARDS due to other causes [23]. We studied E. coli-induced pneumonia, a wellcharacterized animal model that mimics the clinical development of ARDS very closely [23-28]. Intratracheal instillation of $1 \times 10^{11} \mathrm{E}$. coli resulted in physiological and pathologic changes consistent with a severe lung injury over a 6 -hour period, similar to that previously reported [12,13]. Instillation of a lower dose of $5 \times 10^{9}$ E. coli produced a more gradually evolving injury over a 72-hour period, as previously described [14,17].

\section{$\mathrm{NF}-\kappa \mathrm{B}$ : role in lung inflammation}

The role of the NF- $\kappa \mathrm{B}$ signaling in the host immune response to lung injury is increasingly well understood [19]. NF- $\kappa$ B activation pathway gene polymorphisms alter the susceptibility to [29] and severity [30] of clinical ARDS. NF- $\kappa \mathrm{B}$ is a dimer of a number of related proteins, including RelA (also known as P65), p50, p52,
RelB, and cRel, with the RelA and p50 heterodimer, the most common form. On cell activation, by stimuli such as gram-negative bacterial endotoxin, diverse signaling pathways are activated, which converge to phosphorylate and activate the $\mathrm{I} \kappa \mathrm{B}$ kinase complex proteins (IKK), which then phosphorylate and inactivate the $\mathrm{I} \kappa \mathrm{B}$ proteins, which dissociates from NF- $\kappa \mathrm{B}$. The active NF- $\kappa \mathrm{B}$ translocates to the nucleus and binds to specific cognatebinding sequences in the promoter or enhancer regions of different target genes to initiate transcription [5].

The therapeutic potential of strategies to inhibit NF- $\kappa \mathrm{B}$ is evident from the demonstration that NF- $\kappa \mathrm{B}$ inhibition decreases injury in nonseptic ALI models, including pulmonary [6] and systemic reperfusion, and endotoxemia [7]. Pulmonary overexpression of the RelB member of the NF- $\kappa \mathrm{B}$ family decreases cigarette smoke-induced lung injury [31].

\section{ARDS, pneumonia, and NF- $\kappa$ B}

The effects of modulation of the NF- $\kappa \mathrm{B}$ in the setting of lung bacterial infection are less well understood [19]. NF- $\kappa$ B decoy oligodeoxynucleotides reduce ALI in mice in the early phases of cecal ligation and puncture-induced sepsis [8]. Selective inhibition of vascular endothelial NF- $\kappa$ B activity in endotoxemic transgenic mice reduced lung inflammation and increased survival [32]. Of interest, this approach improved survival and systemic organ function, but did not alter bacterial clearance, in septic mice [32]. However, others have found inhibition of NF- $\kappa$ B signaling to exert detrimental effects in the setting of infection. Inhibition of hepatocyte NF- $\kappa \mathrm{B}$ activity reduced Listeria monocytogenes clearance, decreasing murine survival [11]. In contrast, clearance of pseudomonas bacteria from the mouse lung was enhanced by pulmonary overexpression of the RelA subunit of NF- $\kappa$ B [33], suggesting that the NF- $\kappa$ B pathway plays a pivotal role in maintaining immune competence and is essential to eradication of the infectious agent [11].

Table 5 Overexpression of Null or $\mathrm{I} \kappa \mathrm{B} \alpha$ transgenes does not alter lung function or activate the immune response in animals subjected to sham prolonged pneumonia-induced ALI

\begin{tabular}{|c|c|c|c|}
\hline Variable & Vehicle & $\mathrm{I} \kappa \mathrm{B} \alpha$ transgene & Null transgene \\
\hline Number of animals & 4 & 4 & 4 \\
\hline Animal weight (g) & $411 \pm 24$ & $409 \pm 14$ & $395 \pm 11$ \\
\hline Animal survival (n, \%) & $4(100 \%)$ & $4(100 \%)$ & $4(100 \%)$ \\
\hline Duration of animal survival (hours) & $72(72,72)$ & $72(72,72)$ & $72(72,72)$ \\
\hline Final arterial $\mathrm{PO}_{2}(\mathrm{kPa})$ & $18.3 \pm 0.3$ & $17.6 \pm 2.5$ & $18.3 \pm 0.2$ \\
\hline Final static compliance $(\mathrm{ml} / \mathrm{mm} \mathrm{Hg})$ & $0.71 \pm 0.07$ & $0.78 \pm 0.09$ & $0.75 \pm 0.12$ \\
\hline BAL protein $(\mathrm{mg} / \mathrm{L})$ & $961 \pm 221$ & $829 \pm 226$ & $826 \pm 180$ \\
\hline BAL neutrophils $\left(\times 10^{3} / \mathrm{ml}\right)$ & $1.1 \pm 0.7$ & $2.2 \pm 1.7$ & $1.4 \pm 1.2$ \\
\hline BAL mononuclear cells $\left(\times 10^{4} / \mathrm{ml}\right)$ & $5.5 \pm 3.6$ & $5.2 \pm 3.9$ & $3.8 \pm 2.4$ \\
\hline
\end{tabular}

Data are expressed as mean \pm SD or median [interquartile range]. Final data are data collected on completion of the experimental protocol. *Significantly different from Vehicle group. BAL, bronchoalveolar lavage; CFU, colony-forming units 
NF- $\kappa$ B: role in lung inflammation, injury, and repair

NF- $\kappa \mathrm{B}$ also promotes cell survival, resolution of inflammation, and repair after injury. Inhibition of NF- $\kappa \mathrm{B}$ signaling retards pulmonary [20] and intestinal [34] epithelial wound healing. Maturational differences in lung NF- $\kappa \mathrm{B}$ activation profiles exist, with NF- $\kappa \mathrm{B}$ activation protecting the lung against hyperoxia [35] and endotoxemia [36] in neonatal rats. Consequently strategies to inhibit NF- $\kappa \mathrm{B}$, particularly if not spatially or temporally targeted, may have detrimental effects.

\section{Targeting pulmonary NF- $\kappa$ B}

We wished to determine whether inhibition of pulmonary NF- $\kappa$ B activity could modulate the severity of pneumoniainduced lung injury. We found that pulmonary overexpression of the $I \kappa B \alpha$ gene did reduce acute pneumonia-induced injury. $\mathrm{I} \kappa \mathrm{B} \alpha$ decreased the decrement in arterial oxygenation and lung static compliance, decreased alveolar protein leak, and decreased histologic injury, compared with vehicle. $\mathrm{I} \kappa \mathrm{B} \alpha$ modulated the cytokine response to $E$. coli instillation, decreasing alveolar IL-1 $\beta$ but increasing CINC-1 concentrations. Of importance, these effects were dose dependent, with benefit maximal at the intermediate $(1 \times$ $\left.10^{10}\right) I \kappa B \alpha$ dose, and a loss of efficacy at the higher $(1 \times$ $\left.10^{10}\right)$ I $\kappa \alpha \alpha$ concentration.

In contrast, in prolonged untreated $E$. coli pneumonia, pulmonary $I \kappa B \alpha$ gene overexpression worsened the lung injury, and increased lung bacterial load. $\mathrm{I} \kappa \mathrm{B} \alpha$ delayed the resolution of the acute inflammatory response, increasing the proportion of alveolar neutrophils while decreasing alveolar mononuclear cells, which comprise lymphocytes and macrophages and are considered important to repair. I $\kappa \mathrm{B} \alpha$ increased alveolar concentrations of TNF- $\alpha$ and IL$1 \beta$, cytokines implicated in the early phase of the response to septic insult. $\mathrm{I} \kappa \mathrm{B} \alpha$ increased alveolar IL-10 concentrations, which may partly explain the ineffective response to the bacterial insult.

\section{NF- $\kappa$ B and sepsis: an integrated paradigm}

The contrasting effects of NF- $\kappa$ B inhibition in acute versus prolonged pneumonia generate a number of important insights. First, the finding that NF- $\kappa \mathrm{B}$ inhibition reduced the severity of acute pneumonia and decreased the host response induced ALI suggests that any benefit in this setting is mediated via a decreased host response to the instillation of E. coli [37]. This is consistent with the concept that in the early phases of pneumonia, secreted toxins, and the host immune response may be the predominant source of injury $[37,38]$. This is supported by the fact that $\mathrm{NF}-\kappa \mathrm{B}$ inhibition is protective in nonseptic inflammatory ALI models. Second, this effect was dose dependent, with lower and intermediate $\mathrm{I} \kappa \mathrm{B} \alpha$ doses protective and the beneficial effects ablated at higher doses. This suggests a $\mathrm{U}$-shaped dose-effect curve, reducing the therapeutic utility of approaches to inhibit NF- $\kappa \mathrm{B}$ in the setting of acute pneumonia. Third, $\mathrm{I} \kappa \mathrm{B} \alpha$ worsened the severity of prolonged pneumonia, substantially increasing lung bacterial loads, and resulting in a persisting pulmonary inflammatory response. $\mathrm{I} \kappa \mathrm{B} \alpha$, by inhibiting the early host response to $E$. coli instillation, may have led to a persistence of infection, ultimately worsening lung injury. Finally, the beneficial effects of NF- $\kappa$ B inhibition in acute pneumonia were lost at the highest dose. The reasons for this is unclear, but may include NF- $\kappa \mathrm{B}$ inhibition mediated reduction in lung epithelial repair [20], apoptosis of airway epithelial cells [16] and effects on lung macrophage function [39].

\section{Conclusions}

$\mathrm{I} \kappa \mathrm{B} \alpha$ overexpression reduces injury severity and inflammation in early pneumonia, but slows resolution of inflammation and bacterial clearance and worsens injury during prolonged pneumonia. These findings raise serious questions regarding the utility of strategies that inhibit the innate immune response, such as NF- $\kappa \mathrm{B}$, in live bacterial pneumonia.

Key Message: Inhibition of pulmonary NF- $\kappa \mathrm{B}$ activity decreases the severity of early pneumonia-induced lung injury, but worsens injury severity and bacterial load during prolonged pneumonia.

\section{Abbreviations}

AAV: adenoassociated virus; ALI: acute lung injury; ANOVA: analysis of variance; ARDS: acute respiratory distress syndrome; BAL: bronchoalveolar lavage; CINC-1: cytokine-induced neutrophil chemoattractant-1; DNA: deoxyribonucleic acid; E. coli: Escherichia coli; IkBa: inhibitory factor kappa B alpha; IL: interleukin; IQR: interquartile range; KGF: keratinocyte growth factor; qRT-PCR: quantitative real-time polymerase chain reaction; NF-KB: nuclear factor kappa B; PBS: phosphate-buffered saline; RNA: ribonucleic acid; TNF-a: tumor necrosis factor-a

\section{Authors' contributions}

JD performed the animal experiments, assays, and histologic analyses, analyzed the data, drafted the manuscript, and agreed to the final submitted version. GFC and $\mathrm{MH}$ assisted with animal experiments, contributed to drafting the manuscript, and agreed to the final submitted version. CM, BA, and DOT performed assays and histologic analyses, contributed to drafting the manuscript, and agreed to the final submitted version. TOB conceived and designed the experiments, provided viral vector expertise, drafted the manuscript, and agreed to the final submitted version. $J \mathrm{~L}$ conceived and designed the experiments, analyzed the data, drafted the manuscript, and agreed to the final submitted version.

\section{Competing interests}

The authors declare that they have no competing interests.

\section{Acknowledgements}

The authors acknowledge the help of Dr. Shirley Hanley in regard to the FACS analyses, and of Dr Jeremy A. Scott for his critical review of the manuscript. Data from this manuscript were presented at the American Thoracic Society Annual Scientific Meeting, Denver, Colorado, May 2011. This study was funded by the Health Research Board, Ireland and by European Research Council. Dr Devaney is a postdoctoral researcher with the Health Research Board, Ireland (grant RP/2008/193). Dr OToole is a Research Fellow with the European Research Council (grant ERC-2007-StG 
207777). Dr Laffey is supported by a Merit Award from the Department of Anesthesia at the University of Toronto.

\section{Author details}

${ }^{1}$ Regenerative Medicine Institute, National University of Ireland Galway, University Road, Newcastle, Galway, Ireland. 'Department of Anaesthesia and Critical Care, School of Medicine, Clinical Sciences Institute, National University of Ireland Galway, University Road, Newcastle, Galway, Ireland. ${ }^{3}$ Department of Anesthesia, Keenan Research Centre in the Li Ka Shing Knowledge Institute, St. Michael's Hospital, University of Toronto, 30 Bond Street, Toronto, ONT, M5B 1W8, Canada.

Received: 17 January 2013 Revised: 3 April 2013

Accepted: 27 April 2013 Published: 27 April 2013

\section{References}

1. Rubenfeld GD: Epidemiology of acute lung injury. Crit Care Med 2003, 31 S276-284.

2. Zilberberg MD, Epstein SK: Acute lung injury in the medical ICU: comorbid conditions, age, etiology, and hospital outcome. Am J Respir Crit Care Med 1998, 157:1159-1164.

3. Markowicz P, Wolff M, Djedaini K, Cohen Y, Chastre J, Delclaux C, Merrer J, Herman B, Veber B, Fontaine A, et al: Multicenter prospective study of ventilator-associated pneumonia during acute respiratory distress syndrome: incidence, prognosis, and risk factors: ARDS Study Group. Am J Respir Crit Care Med 2000, 161:1942-1948.

4. TenHoor T, Mannino DM, Moss M: Risk factors for ARDS in the United States: analysis of the 1993 National Mortality Followback Study. Chest 2001, 119:1179-1178

5. Park GY, Christman JW: Nuclear factor kappa B is a promising therapeutic target in inflammatory lung disease. Curr Drug Targets 2006, 7:661-668.

6. Ishiyama T, Dharmarajan S, Hayama M, Moriya H, Grapperhaus K, Patterson GA: Inhibition of nuclear factor kappaB by IkappaB superrepressor gene transfer ameliorates ischemia-reperfusion injury after experimental lung transplantation. J Thorac Cardiovasc Surg 2005, 130:194-201.

7. Matsuda N, Hattori Y, Takahashi Y, Nishihira J, Jesmin S, Kobayashi M, Gando S: Therapeutic effect of in vivo transfection of transcription factor decoy to NF-kappaB on septic lung in mice. Am J Physiol 2004, 287:L1248-1255.

8. Matsuda N, Hattori Y, Jesmin S, Gando S: Nuclear factor-kappaB decoy oligodeoxynucleotides prevent acute lung injury in mice with cecal ligation and puncture-induced sepsis. Mol Pharmacol 2005, 67:1018-1025.

9. Rahman A, Fazal F: Blocking NF-kappaB: an inflammatory issue. Proc Am Thorac Soc 2011, 8:497-503.

10. Batra S, Balamayooran G, Sahoo MK: Nuclear factor-kappaB: a key regulator in health and disease of lungs. Arch Immunol Ther Exp 2011, 59:335-351.

11. Lavon I, Goldberg I, Amit S, Landsman L, Jung S, Tsuberi BZ, Barshack I, Kopolovic J, Galun E, Bujard H, et al: High susceptibility to bacterial infection, but no liver dysfunction, in mice compromised for hepatocyte NF-kappaB activation. Nat Med 2000, 6:573-577.

12. O'Croinin DF, Hopkins NO, Moore MM, Boylan JF, McLoughlin P, Laffey JG: Hypercapnic acidosis does not modulate the severity of bacterial pneumonia-induced lung injury. Crit Care Med 2005, 33:2606-2612.

13. Ni Chonghaile M, Higgins BD, Costello JF, Laffey JG: Hypercapnic acidosis attenuates severe acute bacterial pneumonia-induced lung injury by a neutrophil-independent mechanism. Crit Care Med 2008, 36:3135-3144.

14. Chonghaile MN, Higgins BD, Costello J, Laffey JG: Hypercapnic acidosis attenuates lung injury induced by established bacterial pneumonia. Anesthesiology 2008, 109:837-848.

15. Sen S, Conroy S, Hynes SO, McMahon J, O'Doherty A, Bartlett JS, Akhtar Y, Adegbola T, Connolly CE, Sultan S, et al: Gene delivery to the vasculature mediated by low-titre adeno-associated virus serotypes 1 and 5. J Gene Med 2008, 10:143-151.

16. Hassett $P$, Curley GF, Contreras M, Masterson C, Higgins BD, O'Brien T, Devaney J, O'Toole D, Laffey JG: Overexpression of pulmonary extracellular superoxide dismutase attenuates endotoxin-induced acute lung injury. Intensive Care Med 2011, 37:1680-1687.

17. O'Croinin DF, Nichol AD, Hopkins N, Boylan J, O'Brien S, O'Connor C, Laffey JG, McLoughlin P: Sustained hypercapnic acidosis during pulmonary infection increases bacterial load and worsens lung injury. Crit Care Med 2008, 36:2128-2135.

18. Laffey JG, Honan D, Hopkins N, Hyvelin JM, Boylan JF, McLoughlin P: Hypercapnic acidosis attenuates endotoxin-induced acute lung injury. Am J Respir Crit Care Med 2004, 169:46-56.

19. Contreras M, Ansari B, Curley G, Higgins BD, Hassett P, OToole D, Laffey JG: Hypercapnic acidosis attenuates ventilation-induced lung injury by a nuclear factor-kappaB-dependent mechanism. Crit Care Med 2012, 40:2622-2630.

20. O'Toole D, Hassett P, Contreras M, Higgins B, McKeown S, McAuley D, O'Brien T, Laffey J: Hypercapnic acidosis attenuates pulmonary epithelial wound repair by an NF-kB dependent mechanism. Thorax 2009, 64:976-982.

21. Fein AM, Lippmann M, Holtzman H, Eliraz A, Goldberg SK: The risk factors, incidence, and prognosis of ARDS following septicemia. Chest 1983 83:40-42.

22. Martin MA, Silverman HJ: Gram-negative sepsis and the adult respiratory distress syndrome. Clin Infect Dis 1992, 14:1213-1228.

23. Markowicz P, Wolff M, Djedaini K, Cohen Y, Chastre J, Delclaux C, Merrer J, Herman B, Veber B, Fontaine A, et al: Multicenter prospective study of ventilator-associated pneumonia during acute respiratory distress syndrome: incidence, prognosis, and risk factors: ARDS Study Group. Am J Respir Crit Care Med 2000, 161:1942-1948.

24. Freeman BD, Correa R, Karzai W, Natanson C, Patterson M, Banks S, Fitz Y, Danner RL, Wilson L, Eichacker PQ: Controlled trials of rG-CSF and CD11bdirected MAb during hyperoxia and E. coli pneumonia in rats. J Appl Physiol 1996, 80:2066-2076.

25. Karzai W, von Specht BU, Parent C, Haberstroh J, Wollersen K, Natanson C, Banks SM, Eichacker PQ: G-CSF during Escherichia coli versus Staphylococcus aureus pneumonia in rats has fundamentally different and opposite effects. Am J Respir Crit Care Med 1999, 159:1377-1382.

26. Russo TA, Bartholomew LA, Davidson BA, Helinski JD, Carlino UB, Knight PR, Beers MF, Atochina EN, Notter $\mathrm{RH}$, Holm BA: Total extracellular surfactant is increased but abnormal in a rat model of gram-negative bacterial pneumonia. Am J Physiol Lung Cell Mol Physiol 2002, 283:L655-663.

27. Song GW, Robertson B, Curstedt T, Gan XZ, Huang WX: Surfactant treatment in experimental Escherichia coli pneumonia. Acta Anaesthesiol Scand 1996, 40:1154-1160.

28. Zeni F, Parent C, Correa R, Natanson C, Freeman B, Fontana J, Quezado M, Danner RL, Fitz Y, Richmond S, et al: ICAM-1 and CD11b inhibition worsen outcome in rats with E. coli pneumonia. J App/ Physiol 1999, 87:299-307.

29. Zhai R, Zhou W, Gong MN, Thompson BT, Su L, Yu C, Kraft P, Christiani DC: Inhibitor kappaB-alpha haplotype GTC is associated with susceptibility to acute respiratory distress syndrome in Caucasians. Crit Care Med 2007, 35:893-898.

30. Adamzik M, Frey UH, Rieman K, Sixt S, Beiderlinden M, Siffert W, Peters J: Insertion/deletion polymorphism in the promoter of NFKB1 influences severity but not mortality of acute respiratory distress syndrome. Intensive Care Med 2007, 33:1199-1203.

31. McMillan DH, Baglole CJ, Thatcher TH, Maggirwar S, Sime PJ, Phipps RP: Lung-targeted overexpression of the NF-kappaB member RelB inhibits cigarette smoke-induced inflammation. Am J Pathol 2011, 179:125-133.

32. Ye X, Ding J, Zhou X, Chen G, Liu SF: Divergent roles of endothelial NFkappaB in multiple organ injury and bacterial clearance in mouse models of sepsis. J Exp Med 2008, 205:1303-1315.

33. Sadikot RT, Zeng $H$, Joo M, Everhart MB, Sherrill TP, Li B, Cheng DS, Yull FE, Christman JW, Blackwell TS: Targeted immunomodulation of the NFkappaB pathway in airway epithelium impacts host defense against Pseudomonas aeruginosa. J Immunol 2006, 176:4923-4930.

34. Egan LJ, Eckmann L, Greten FR, Chae S, Li ZW, Myhre GM, Robine S, Karin M, Kagnoff MF: IkappaB-kinasebeta-dependent NF-kappaB activation provides radioprotection to the intestinal epithelium. Proc Natl Acad Sci USA 2004, 101:2452-2457.

35. Yang G, Abate A, George AG, Weng YH, Dennery PA: Maturational differences in lung NF-kappaB activation and their role in tolerance to hyperoxia. J Clin Invest 2004, 114:669-678.

36. Alvira CM, Abate A, Yang G, Dennery PA, Rabinovitch M: Nuclear factorkappaB activation in neonatal mouse lung protects against lipopolysaccharide-induced inflammation. Am J Respir Crit Care Med 2007, 175:805-815. 
37. Curley G, Contreras MM, Nichol AD, Higgins BD, Laffey JG: Hypercapnia and acidosis in sepsis: a double-edged sword? Anesthesiology 2010, 112:462-472.

38. Laffey JG, O'Croinin D, McLoughlin P, Kavanagh BP: Permissive hypercapnia: role in protective lung ventilatory strategies. Intensive Care Med 2004, 30:347-356.

39. Groesdonk HV, Schlottmann S, Richter F, Georgieff M, Senftleben U: Escherichia coli prevents phagocytosis-induced death of macrophages via classical NF-kappaB signaling, a link to T-cell activation. Infect Immun 2006, 74:5989-6000.

doi:10.1186/cc12696

Cite this article as: Devaney et al: Inhibition of pulmonary nuclear factor kappa-B decreases the severity of acute Escherichia coli pneumonia but worsens prolonged pneumonia. Critical Care 201317 R82.

\section{Submit your next manuscript to BioMed Central} and take full advantage of:

- Convenient online submission

- Thorough peer review

- No space constraints or color figure charges

- Immediate publication on acceptance

- Inclusion in PubMed, CAS, Scopus and Google Scholar

- Research which is freely available for redistribution

Submit your manuscript at www.biomedcentral.com/submit 